\title{
Effect of Moringa oleifera Feed Supplements on All-Male Tilapia Growth Performance at Tano-Dumasi Pilot Aquaculture Centre
}

\author{
Benjamin Makimilua Tiimub ${ }^{1,2^{*}}$, Isaac Kwadwo Mpanga ${ }^{2}$, Gideon Likida Tiimob ${ }^{3}$, Richard Wonnsibe Tiimob ${ }^{4}$, Isaac \\ Baani $^{2}$ and Ernestina Laatman Tiimob ${ }^{5}$ \\ ${ }^{1}$ Department of Environmental Engineering, College of Environmental and Resource Sciences, Zhejiang University, 310058, Hangzhou P. R. China \\ ${ }^{2}$ Department of Environmental Health and Sanitation Education, Faculty of Science and Environment Education, College of Agriculture Education \\ (CAGRIC), University of Education, Winneba, Ashanti Mampong Campus, Ghana. \\ ${ }^{3}$ Specialist at Supervisory Section (Public Health \& Nutrition) - Catholic Relief Service, Tamale \\ ${ }^{4}$ Specialist in Community Health \& Development \& Instructor, Science Department, Savelugu SHS, Ghana Education Service, Tamale, Northern \\ Region \\ ${ }^{5}$ Business Senior High School, Tamale, Northern Region, Ghana
}

\section{Article History \\ Received: 01.10 .2020 \\ Accepted: 15.10 .2020 \\ Published: 30.10 .2020}

Journal homepage:

https://www.easpublisher.com/easjbg

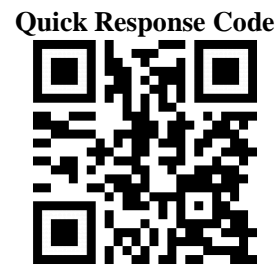

Abstract: The study was conducted to find out the effects of Moringa oleifera leaves and seeds as a supplementary feed on the growth performance of all-male tilapia. The main objectives of the study were to determine effects of the supplementary feed (leaves + normal feed, seeds + normal feed, leaves + seeds + normal feed) on all male tilapia in terms of their average standard length, total length, standard width, total width and weight. The parameters for each of the treatments were measured fortnightly over the entire eight weeks period. The sample covered a total population of 260 fishes - 20 each from the hapa and 60 from each of the 4 ponds. The results revealed significant differences among the treatments (normal feed, leaves + normal feed, seeds + normal feed, leaves + seeds + normal feed) used on the parameters measured (average: standard length, total length, standard width, total width and weight) at $(p<0.05)$. The results clearly demonstrated that the seeds recorded higher (best growth) performance in terms of the parameters measured than all the other treatments administered. This was followed by combination of seeds and leaves with the normal feed only recording the least performance.

Keywords: Moringa, All male tilapia, Standard width, Standard length, Standard weight, Hapa, Pond.

Copyright ( 92020 The Author(s): This is an open-access article distributed under the terms of the Creative Commons Attribution 4.0 International License (CC BY-NC 4.0) which permits unrestricted use, distribution, and reproduction in any medium for non-commercial use provided the original author and source are credited.

\section{INTRODUCTION}

According to Naylor et al., [1] as the World's human population continues to expand beyond 6 billion, its reliance on farmed fish production as an important source of protein will also increase. Projections of world fishery production in 2010 ranged between 107 and 144 million tonnes [2]. Most of the increase in fish production is expected to come from aquaculture, which is currently the fastest growing food production sector of the world. By the year 2030, aquaculture will dominate fish supplies and more than half of the fish consumed is likely to originate from this sector [2]. The projected total production of feeds for aquaculture in the year 2010 ranged from 25 million metric tonnes (mmt); [3] to $32.6 \mathrm{mmt}$ [4] against an approximate production estimate of about $13 \mathrm{mmt}$ in the year 2000 . Requirements for aquaculture feeds are likely to be further increased by an increasing trend towards the intensification of farmed production of omnivorous species in Asian countries, particularly China.
Protein is an essential food nutrient which must be present in the requisite amount in the diet of every human being. It is needed for formation of enzymes, hormones; body building, repairs of warn out tissues and also serves as a source of energy to the body [5]. The deficiency of protein in the diet of children results in "kwashiorkor", a disease that makes infants have distended bellies, stunted growth, slowed movement and become emotionally stressed [6]. According to FAO [7], the recommended protein (animal) requirement for a person is $49 \mathrm{~g}$. However, in Ghana protein per head per day from animal source is estimated to be $13.4 \mathrm{~g}$ which is far below estimate of the FAO. The very important role proteins play in our diet and insufficiency of protein in Ghana calls for an increase in the supply of protein through tilapia production [8]. The fishery sector contributed about $3.9 \%$ of the gross national product (GDP) and $11 \%$ of Agriculture GDP as of 2008. The sector currently contributes significantly to Ghana's economy in terms of food security, employment, poverty alleviation, GDP and foreign exchange revenues. The contribution of Ghana's fisheries sector is important, amounting to 4.5 
$\%$ of the GDP (an incremental growth rate of $0.6 \%$ within eight years), $12 \%$ of the agricultural GDP and $10 \%$ of the labor force (supporting livelihoods of $10 \%$ ) of Ghana's population of about 26 million people. Also, worthy of mention is the sector's gender balance. While men are involved in fishing proper in the artisanal, semi-industrial and industrial sectors, women engage in onshore postharvest activities, undertaking fish processing, storage and distribution, even onto external markets [9]. For a long time, fish has remained the cheapest and the preferred animal proteins source with about $75 \%$ of total production being consumed locally. In Ghana the average per capital fish consumption is said to be around 20 to $25 \mathrm{~kg}$ which is higher than the world average of $13 \mathrm{~kg}$. Importantly, about $60 \%$ of animal protein in Ghanaian diets country-wide is thought to be from fish which accounts for $22.4 \%$ of household expenditure.

Fish farming started in Ghana when fish ponds were built in 1953 by the former department of fisheries in northern Ghana. Tilapia is the major species and contributes over $80 \%$ of aqua-culture production. The production from ponds and culture-based fisheries is worth about US $\$ 1.5$ million a year (ministry of fisheries). According to previous 2007 Ghana budget statement, the country's total fish requirement was estimated at 720000 metric tons (mt), whiles annual production average is $400000 \mathrm{mt}$. This left annual deficit of $320000 \mathrm{mt}$ which was made up through the importation of US \$200 Million worth of fish into the country. Over the years, the fishing industry in Ghana depends on resources from the marine and inland (freshwater) sectors and coastal lagoons. Total capture fisheries production was approximately 298000 tonnes in 2013; around 24 percent of this production (90 000 tonnes) emanated from inland fisheries mostly based on the largest man-made Volta Lake in Africa [9]. Production from marine fisheries has been declining since 1999, from almost $420000 \mathrm{mmt}$ to $202000 \mathrm{mmt}$ in 2014. Total fish exports peaked in 2003 valued at USD 120 million but declined sharply to USD 44 million, while the peak of total quantity fish export was $60000 \mathrm{mmt}$ in 2001. In order to sustain the per capita annual consumption of fish (about $24.2 \mathrm{~kg}$ in 2010), imports have increased substantially in the most recent years, reaching USD 373 million in 2013. As a result, the seafood trade balance moved from a USD 33 million surplus in 1997 to a USD 319 million deficit in 2013. It is estimated that the fisheries, mostly artisanal, employ over 29300 fishing vessels, more than half without engine, and involve over 250000 fishers. Recently, fish farming has grown rapidly from 1200 tonnes in 2005 to 38500 tonnes in 2014, spurred by high prices of tilapia, the quickly expanding cage farming in the Volta Basin and the high level of government interest and commitment. Tilapias constituted over 90 percent of the total aquaculture harvest. The Government has placed aquaculture as one of the top priorities in the country's development agenda and substantial support is being given to fish farmers in various aspects of the industry. Aquaculture is also being promoted through restocking programs in Lake Volta, reservoirs and other water bodies and the rehabilitation of hatcheries and aquaculture demonstration centers [9].

According to Hardy [10], the proportion of global fishmeal production used in fish feeds has increased from 10 to 35 per cent in the last fifteen years. A prediction of fishmeal needs for aquaculture feeds in 2010 was 2.8 million metric tons ( $\mathrm{mmt}$ ), approximately 44 per cent of the ten-year average global fishmeal production of $6.5 \mathrm{mmt}$. This was in spite of the predicted decrease from current levels of the percentage of fishmeal included in the feed of all major aquaculture species. Hardy [10] estimates that this amount of fishmeal would be approximately $1.3 \mathrm{mmt}$ less than that required had there been no decline in fishmeal use in fish feeds. At least this amount of fishmeal equivalent alternative protein sources (to the order of approximately $3 \mathrm{mmt}$ ) was required in the aquaculture industry yearly as at 2010 .

The problem identified, thus necessitating for this research was clearly diagnosed as justifiable from existing literature. It was expected that this project will demonstrate results that will help fish farmers in tilapia production to increase their production, through the use of moringa leaves and seeds such that the average Ghanaian can afford to buy tilapia to increase their protein consumption [8]. Virtually, Ghanaians could reduce the importation of fish and increase the exportation of tilapia which will significantly increase the GDP of the country. The project once found successful, could be scaled up to reduce the dependency pressure on fish as fishmeal which should have been used as food by humans. The findings will also enhance scientific study/research in biology, fisheries or aquaculture and general agriculture as well as ecology in both second cycle institutions and tertiary level of Ghanaian education since fish biology and ecology constitute relevant aspects of various curriculum designs. According to Tacon and Forster [3], the need to identify appropriate, new sources of protein is therefore imperative once the selected protein sources do not conflict with human food security interests. It is justifiable in the context that fish that could form human food are converted into fishmeal for use in animal feeds in countries such as Peru for economic reasons. The importance of the development of nonhuman-food grade feed resources whose growth can cope with the projected and desired fast growth of the sector has been stressed. Also, recent disease outbreaks such as Bovine Spongiform Encephalothapy (BSE) in livestock, arguably caused by feeding animal products to animals that do not normally consume them; have cast doubts regarding the suitability of feeding animalderived proteins to non-carnivorous species. Plants therefore become the preferred sources of protein for 
these species. There have been a number of efforts in the past decades to test the suitability of a number of plant-derived protein sources for various, popular aquaculture species. Many of these have concentrated on species such as soybean, rapeseed (canola) meal, sunflower seed meal, cottonseed meal, peanut meal, and wheat and corn gluten. Most of these plants require environmental and soil conditions and energy subsidies that restrict the scope for increasing their production. With the prospects of increasing direct human demand for nutrients derived from these sources they could not be expected to contribute greatly towards satisfying demands from new sources such as the aquaculture feed industry [8]. There was, therefore, a need to examine other plants that can grow on degraded soil and require lower external energy subsidies alongside their potential in the production of feed ingredients and reclamation of degraded areas. Furthermore, their development may be aided by the national, international and private funding that is being channeled into wasteland.

One of the critical nutritional problems in Ghana and other developing countries is that of protein deficiency. FAO [2] reported that $15 \%$ of the world's population suffers protein deficiency. This occurs mainly in Africa and part of Asia. Insufficient intake of protein results in protein malnutrition (P.E.M.). According to WHO [11], report, P.E.M. is by far the lethal form of malnutrition and it accounts for about half of the 10.7 million children who die each year. Not only does P.E.M. affect children but also adult and most especially pregnant women. P.E.M. In pregnant women it can lead to ill-health, low child-birth weight, abortion and worst of all maternal death. The conventional feeds used by farmers seem to have low effect on fish production, competition for human protein sources and continues to make fish (tilapia) expensive due to population growth and making it difficult for the ordinary Ghanaians to afford this product [8]. The study mainly focused on the use moringa leaves and seeds as innovative supplemental feed to improve the performance (weight) of tilapia. It specifically demonstrated the different aspects of fish growth response to feeding in trial experiments by objectively comparing the growth performances under comparative analyses of: [1. Average body weight (AW); 2. Average total length (ATL); 3. Average standard length (ASL); 4. Average total width (ATW) and 5. Average standard width (ASW)], at Tano-Dumasi Pilot Aquaculture Centre.

\section{HYPOTHESIS}

Null hypothesis: there is no significant difference between the treatments used $(\mathrm{T} 0=\mathrm{T} 1=\mathrm{T} 2=$ T3). Alternative hypothesis: there is a significant difference between the treatments used $(\mathrm{T} 0 \neq \mathrm{T} 1 \neq \mathrm{T} 2 \neq \mathrm{T} 3)$ : where, $\mathrm{T} 0=$ normal feed used for feeding; $\mathrm{T} 1=$ normal feed plus moringa leaves; $\mathrm{T} 2=$ normal feed plus the moringa seeds and $\mathrm{T} 3=$ normal feed plus moringa leaves and seeds.

\section{RELEVANT LITERATURE General information on Moringa oleifera}

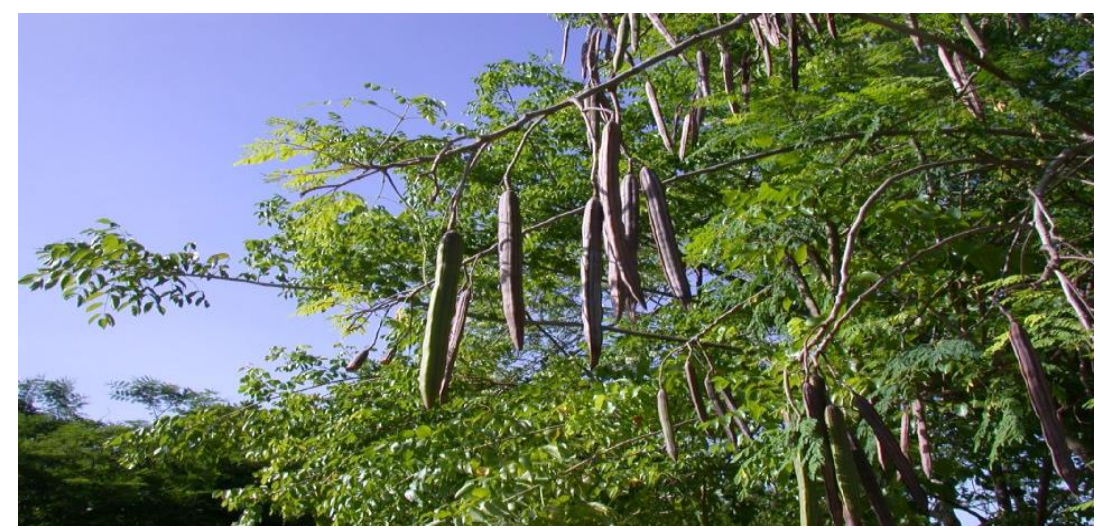

Plate-1: A Moringa tree exhibiting leaves and pods

According to Foidl et al., [12] Moringa oleifera Lam or 'horse-radish' tree (so-called because of the taste of a condiment prepared from the roots) or 'drumstick' tree (arising from the shape of the pods), or 'never-die-tree' is a multipurpose tree that thrives in both tropical and sub-tropical conditions. It is native to the sub-Himalayan regions of north-west India. This tree is now indigenous to many countries in Africa, Arabia, South East Asia, the Pacific and Caribbean Islands and South America, producing flowers and fruits continuously. Originally considered a tree of hot, semi-arid regions with annual rainfall $250-1500 \mathrm{~mm}$, it has also been found to be well adapted to hot, humid, wet conditions with annual rainfall in excess of 3000 $\mathrm{mm}$. Moringa can grow in a variety of soil conditions, from well drained sandy or loamy soils (which the plants prefer) to heavier clay soils. The tree is reported to be tolerant of light frosts and can be established in slightly alkaline soils up to $p \mathrm{H} \mathrm{9}$. Currently, the young leaves and pods are used as vegetables, the oil extracted 
from kernels for culinary and industrial purposes, the water extract of the kernels as water purifying agent, the seed cake as fertilizer, and various parts of the tree in traditional medicine.

According to Makkar and Becker [13], moringa tree is fast growing and high yielding (an estimated $3.0 \mathrm{t}$ seed / ha compared to average yields of sunflower and groundnut of 2.0 and $0.5 \mathrm{t} / \mathrm{ha}$ respectively). It can also be planted for forage production under intensive farming conditions. Initial trials in Nicaragua have shown a high biomass production of up to 120 tons dry matter / ha / year, in eight cuttings after planting 1 million seeds / ha. The plant starts bearing pods $6-8$ months after planting but regular bearing commences after the second year. The tree bears for 30 - 40 years. The drought tolerant nature of the tree makes it particularly suited to those marginal areas where the costs associated with the cultivation and harvesting of other commercial crops are high.

\section{Nutrient composition of Moringa oleifera}

The seed kernel contains, on average, $40 \%$ by weight of oil, the fatty acid composition of which is similar to that of olive oil and could be used for both culinary and industrial purposes. The seed oil contains 9.3\% palmitic, $7.4 \%$ stearic, $8.6 \%$ behenic, and $65.7 \%$ oleic acids among the fatty acids. Myristic and lignoceric acids have also been reported. In addition to high macronutrient content (Table 1), moringa leaves and seeds are also rich in vitamins and minerals. Leaves (100g) contain $440 \mathrm{mg} \mathrm{Ca}, 70 \mathrm{mg} \mathrm{P,} 7 \mathrm{mg} \mathrm{Fe}, 110 \mathrm{mg}$ $\mathrm{Cu}, 5.1 \mathrm{mg}$ I, 11,300 IU pro-vitamin A, $120 \mathrm{mg}$ vitamin $\mathrm{B}, 0.8 \mathrm{mg}$ nicotinic acid, $220 \mathrm{mg}$ ascorbic acid, and 7.4 $\mathrm{mg}$ tocopherol per $100 \mathrm{~g}$. Per $100 \mathrm{~g}$, the pod is reported to contain $30 \mathrm{mg} \mathrm{Ca}, 110 \mathrm{mg} \mathrm{P}, 5.3 \mathrm{mg} \mathrm{Fe}, 184$ IU provitamin A, $0.2 \mathrm{mg}$ niacin, $120 \mathrm{mg}$ ascorbic acid, $310 \mathrm{mg}$ $\mathrm{Cu}$, and $1.8 \mathrm{mg} \mathrm{I}$.

According to Makkar and Becker [13] the high true protein content of leaves $(23 \%)$, the high proportion of this protein potentially available in the intestine, the presence of adequate levels of essential amino acids (higher than the levels present in the FAO reference protein), and low levels of anti-nutrients indicate their high nutritional quality. The high pepsin soluble nitrogen $(82-91 \%)$ and the low acid detergent insoluble protein $(1-2 \%)$ values for the meal suggest that most of the protein in the meal is available to most animals. The meal is deficient in lysine, leucine, phenylalanine + tyrosine and threonine when compared to the standard FAO protein but the contents of sulphurcontaining amino acids in these samples are much higher (Table 3).

\section{Anti-nutrients}

Moringa leaves are free from anti nutrients except for saponins and phenols (Table 2). The concentration of phenol is much below the toxic threshold levels for animals and saponins were inactive as far as haemolytic properties are concerned. In addition to the anti-nutrients listed in Table 2, alkaloids are also present in kernel meals (root-bark have been found to have two alkaloids, moringine and moringinine; moringinine is known to stimulate cardiac activity, raise blood-pressure, act on sympathetic nerveendings as well as smooth muscles all over the body, and depress the sympathetic motor fibres of vessels in large doses only) [13].

Table-1 : Chemical composition of Moringa oleifera parts (\% dry matter)

\begin{tabular}{|c|c|c|}
\hline Substance & Leaves & Kernels \\
\hline Crude protein & 26.4 & 36.7 \\
\hline Lipids & ND & 41.7 \\
\hline Ash & 8.87 & 3.8 \\
\hline Neutral detergent & 5.51 & 4.8 \\
\hline Gross energy (MJ/kg) & 19.35 & 26.1 \\
\hline
\end{tabular}

Source: Makkar et al. [13]

Table-2: Important anti nutrient factors present in Moringa oleifera parts

\begin{tabular}{|c|c|c|}
\hline Substance & Leaves & Kernels \\
\hline Total phenols (\% tannic acid equivalent) & 4.4 & 0.02 \\
\hline Tannins (\% tanic acid equivalent) & 1.2 & $\mathrm{ND}$ \\
\hline Saponins (\% diosgenin equivalent) & 8.1 & 1.1 \\
\hline Phytate (\% dry matter) & 2.1 & 2.6 \\
\hline Lectins (1/mg of meal that produced & DN & Variable $(15 / 16.5 / 250)$ \\
\hline Haemaghtination per lm of assay medium & DN & 0.5 \\
\hline Cyanogenic glycosides $(\%)$ & DN & 56.6 \\
\hline
\end{tabular}

Source: Makkar et al. [13] 
Table-3: Composition of important amino acids of seeds/parts (g/16gN) compared with fishmeal.

\begin{tabular}{|c|c|c|c|}
\hline Amino acids & Fishmeal & Moringa leavs & Moringa kernels \\
\hline Methionine & 3.12 & 1.98 & 1.90 \\
\hline Cystine & 1.19 & 1.35 & 4.22 \\
\hline Valine & 5.84 & 5.68 & 3.47 \\
\hline Isolencine & 4.70 & 4.50 & 3.05 \\
\hline Histidine & 2.10 & 2.99 & 2.27 \\
\hline Lencine & 8.09 & 8.70 & 5.27 \\
\hline Phenylalanine & 4.03 & 6.18 & 3.97 \\
\hline Lysine & 7.38 & 5.60 & 1.47 \\
\hline Tyrosine & 3.01 & 3.87 & 1.50 \\
\hline Arginine & 7.18 & 6.23 & 11.6 \\
\hline Threonine & 4.52 & 4.66 & 2.25 \\
\hline Tryptophan & 1.13 & 2.10 & NA \\
\hline \multicolumn{4}{|l|}{ Source: Makkar and Becker [13]. }
\end{tabular}

\section{Literature on Tilapia}

Taxonomy (refer to appendix table 2)

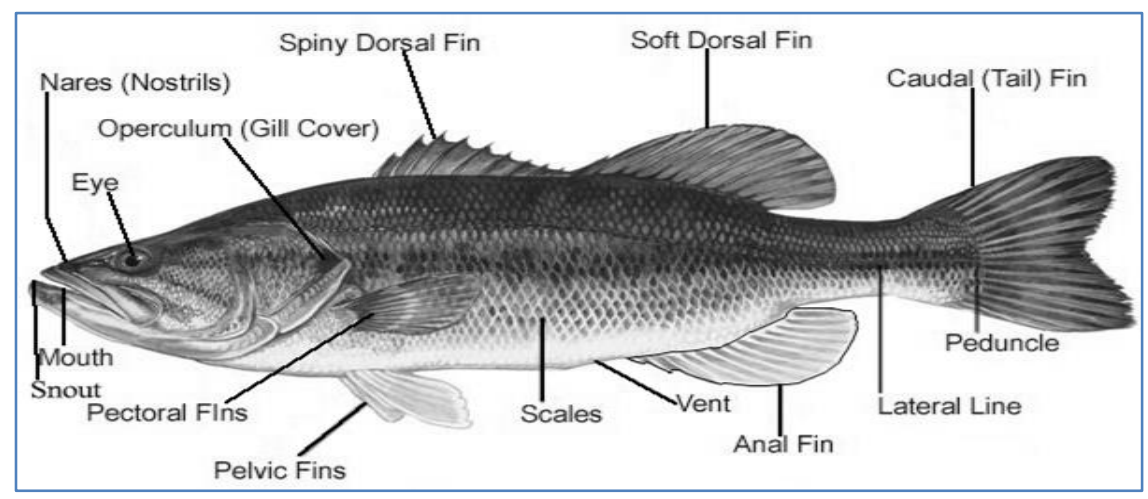

Fig-1: External Anatomy of Tilapia (FWC, 2001 - 2020).

Fishes are cold-blooded animals with fins and a backbone. Most fish have scales and breathe with gills. There are about 22,000 species of fish that began evolving around 480 million years ago. The largemouth bass illustrated above has the typical torpedo-like (fusiform) shape associated with many fishes. Fins are appendages used by the fish to maintain its position, move, steer and stop. They are either single fins along the centerline of the fish, such as the dorsal (back) fins, caudal (tail) fin and anal fin, or paired fins, which include the pectoral (chest) and pelvic (hip) fins. The dorsal and anal fins primarily help fish to not roll over onto their sides. The caudal fin is the main fin for propulsion to move the fish forward. The paired fins assist with steering, stopping and hovering. Scales in most bony fishes (most freshwater fishes other than gar that have ganoid scales), and are either ctenoid or cycloid. Ctenoid scales have jagged edges and cycloid have smooth rounded edges. Bass and most other fish with spines have ctenoid scales composed of connective tissue covered with calcium. Most fishes also have a very important mucus layer covering the body that helps prevent infection. The soft dorsal and caudal fins are composed of rays, as are portions of other fins. Rays are less rigid and frequently branched. The gills are the breathing apparatus of fish and are highly vascularized giving them their bright red cover. An operculum (gill cover) that is a flexible bony plate protects the sensitive gills. Water is "inhaled" through the mouth, passes over the gills and "exhaled" from beneath the operculum. Fish see through their eyes and can detect colour. The eyes are rounder in fish than mammals because of the refractive index of water and focus is achieved by moving the lens in and out, not distorting it as in mammals [14].

Paired nostrils, or nares, in fish are used to detect odours in water and can be quite sensitive. The mouth's shape is a good clue to what fish eat. The larger it is the bigger the prey it can consume. Fish have a sense of taste and may sample items to taste them before swallowing if they are not obvious prey items. Most freshwater fishes are omnivorous (eating both plant and animal matter). Some are primarily piscivorous (eating mostly other fish). The imported grass carp is one of the few large fishes that are primarily herbivorous (eating plants). Fish may or may not have teeth depending on the species. The lateral line is a sensory organ consisting of fluid filled sacs with hair-like sensory apparatus that are open to the water through a series of pores (creating a line along the side of the fish). The lateral line primarily senses water 
currents and pressure, and movement in the water. The vent is the external opening to digestive urinary and reproductive tracts. In most fish it is immediately in front of the anal fin [14].

\section{Internal Anatomy of Fish}

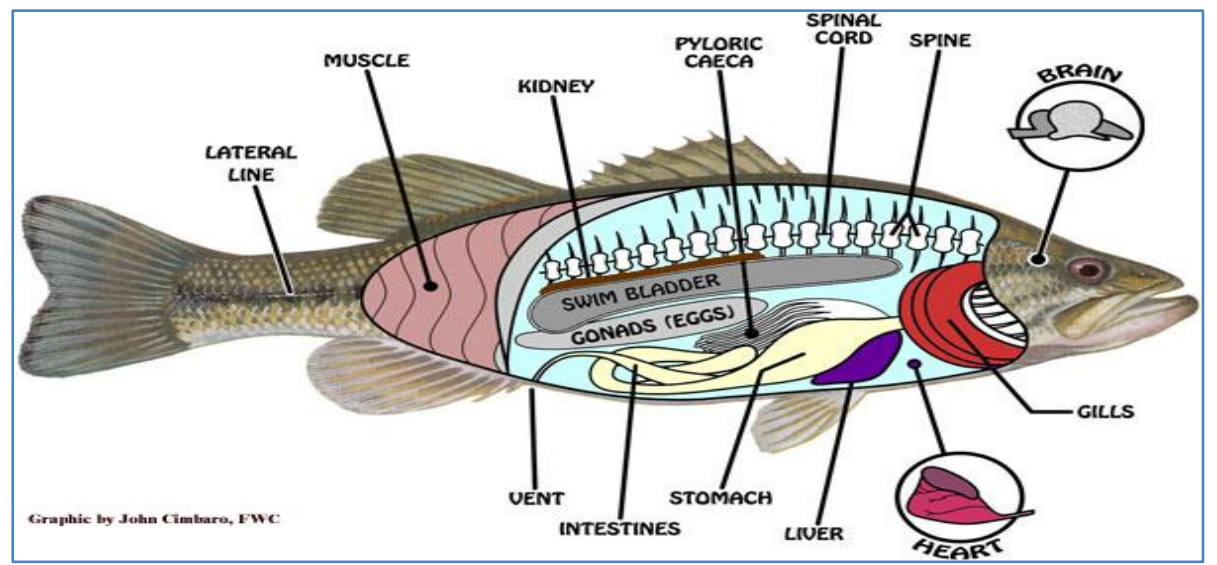

Fig-2: Internal Anatomy of Tilapia [14].

As different as a man may be from a fish, both creatures share some fascinating similarities in basic structure and functions. And the closer one looks; the more complex life becomes. The smallest units of life are microscopic cells, and some organisms such as an amoeba are not larger than a single cell. In larger multicellular creatures, individual cells that are similar in structure and perform a specific function are grouped into tissues, and tissues may be grouped into even more complex and specialized structures called organs. These organs perform the basic bodily functions such as respiration, digestion, and sensory reception. Humans and fish share such organs as the brain, stomach, liver, and kidneys. Other organs appear in different forms in different organisms; for example, the lungs in humans and the gills in fish are very different but both provide the same basic function of respiration. Finally, some organs (such as the fish's swim bladder) are simply not present in man. Below are descriptions of some of the organs identified on the above diagram, along with their functions. A number of other vital organs, such as the spleen and pancreas, may also be present but are smaller and more difficult to locate [14].

\section{Spine}

The primary structural framework upon which the fish's body is built is the spine. It connects to the skull at the front of the fish and to the tail at the rear. The spine is made up of numerous vertebrates, which are hollow and house and protect the delicate spinal cord [14].

\section{Spinal cord}

The spinal cord connects the brain to the rest of the body and relays sensory information from the body to the brain, as well as instructions from the brain to the rest of the body [14].
Brain

The brain is the control centre of the fish, where both automatic functions (such as respiration) and higher behaviours ("Should I eat that critter with the spinning blades") occur. All sensory information is processed here [14].

\section{Lateral line}

The lateral line is one of the fish's primary sense organs; detects underwater vibrations and is capable of determining the direction of their source [14].

\section{Swim (or air) bladder}

The bladder is a hollow, gas-filled balance organ that allows a fish to conserve energy by maintaining neutral buoyancy (suspending) in water. Fish caught from very deep water sometimes need to have air released from their swim bladder before they can be released and returned to deep water, due to the difference in atmospheric pressure at the water's surface. Species of fish that do not possess a swim bladder sink to the bottom if they stop swimming [14].

\section{Gills}

Gills allow a fish to breathe underwater. These are very delicate structures and should not be touched by hand [14].

Kidney

The kidney filters liquid waste materials from the blood; these wastes are then passed out of the body. The kidney is also extremely important in regulating water and salt concentrations within the fish's body, allowing certain fish species to exist in freshwater or saltwater, and in some cases (such as snook, tarpon, salmon, et cetera) both [14]. 


\section{Stomach and intestines}

The stomach and intestines are organs that break down (digest) food and absorb nutrients. Fish such as bass that are piscivorous (eat other fish) have fairly short intestines because such food is easy to chemically break down and digest. Fish such as tilapia that are herbivorous (eat plants) require longer intestines because plant matter is usually tough and fibrous and more difficult to break down into usable components. A great deal about fish feeding habits can be determined by examining stomach contents [14].

\section{Pyloric caeca}

The pyloric caeca is an organ with finger like projections, located near the junction of the stomach and the intestines. Its function is not entirely understood, but it is known to secrete enzymes that aid in digestion, may function to absorb digested food, or do both [14].

\section{Vent}

Vent is the site of waste elimination from the fish's body [14].

\section{Liver}

The liver as an important organ has a number of functions. It assists in digestion by secreting enzymes that break down fats, and also serves as a storage area for fats and carbohydrates. The liver also is important in the destruction of old blood cells and in maintaining proper blood chemistry, as well as playing a role in nitrogen (waste) excretion [14].

\section{Heart}

The heart circulates blood throughout the body. Oxygen and digested nutrients are delivered to the cells of various organs through the blood, and the blood transports waste products from the cells to the kidneys and liver for elimination [14].

\section{Gonads}

Gonads are the reproductive organs in fishes. In adult female bass, the bright orange mass of eggs is unmistakable during the spawning season, but is still usually identifiable at other times of the year. The male organs, which produce milt for fertilizing the eggs, are much smaller and white but found in the same general location. The eggs (or roe) of certain fishes are considered a delicacy, as in the case of caviar from sturgeon [14].

\section{Muscles}

Muscles provide movement and locomotion. This is the part of the fish that is usually eaten, and composes the fillet of the fish [14].

\section{Juvenile and Adult Morphology}

Caudal fin of tilapia is with regular dark vertical stripes. Dorsal fin is tripped with dark margin. There is red coloration on head and lower part of the body in breeding males. Variable coloration in females is dependent on subspecies- some may show coloration similar to males during breeding season [14].

\section{Distinguishing Characteristics}

Nile tilapia is unlikely to be confused with native North American species though they look similar and both have historically been confused with the blue tilapia, Oreochromis aureus. Caudal fin of the Nile tilapia is with regular dark vertical stripes but it is with vague or variable stripes in $O$. aureus. Nile tilapia lacks the intense metallic blue on head of breeding males as in O. aureus. Typically, Nile tilapia has, higher number of dorsal spines (16-18 in O. niloticus and 15-16 in $O$. aureus) (refer to the Nile tilapia breed profile in appendix table 2) [15].

\section{General Biology \\ Behavior}

During the day tilapias may form large schools that break up at the night and reform at dawn [15].

\section{Diet}

Juveniles fishes have diurnal feeding pattern, posing as omnivorous and the fry primarily consume copepods, hydracarines and insects and by $6 \mathrm{~cm}$ total body length, the diet becomes primarily phytoplankton. Adults also have diurnal feeding pattern and primarily utilize phytoplankton (blue-green algae and diatoms) but may also consume macrophytes when phytoplankton densities are low [15].

\section{Life Cycle \\ Growth}

According to Farming Pedia (FP), Nile tilapia attains maximum size of $64 \mathrm{~mm}$ total body length at reproductive maturity stage and a total length of $25 \mathrm{~cm}$ by second year [15].

\section{Maturity}

According to Duponchelle and Panfili [16], Total length at first sexual maturity of Nile tilapia ranges from 9 to $15 \mathrm{~cm}$. Size at maturity is also positively correlated to maximum size observed in the population. Age at maturity occurs in first year between 5 and 10 months. Female fecundity ranges from 149 to 2797 ova for fish between 36 and $975 \mathrm{~g}$ [15].

\section{Spawning}

According to Turner and Robinson [17], spawning occurs between April and May in Israel. In Nile delta spawning is more protracted - from April to August. Reproduction is usually first observed at a temperature of $19{ }^{\circ} \mathrm{C}$ whereby, males construct simple crater-shaped nests in sand or mud for eggs to be laid in. Nests are two times the male length or up to $1 \mathrm{~m}$ in diameter. Spawning habitat are variable ranging from firm sand to muddy lagoons to steep lava shores. Females form school above the nests and swim in a circular motion. No lasting pair-bond is retained during 
breeding season and both male and female clean nest. Eggs are laid in approximately 20 batches over a 45 minutes to 2-hour period. Female picks up the eggs as soon as they are laid and fertilized. Females develop a characteristic coloration pattern while brooding young (dark stripes across forehead and a dark operculum, chin, and eye). A single female may have several size classes of ova in the ovaries at any one time- indicating multiple spawns in a single season.

\section{Eggs}

According to Duponchelle et al. [18], the Nile tilapia eggs are 3.0-3.4 x 2.2-2.5mm longest in diameter when mature. Eggs are yellow and pear-shaped. The female rolls eggs in her mouth during incubation. A female may brood up to 2000 eggs at a go. Hatching occurs at 4-5 days giving rise to fries that are $4.5 \mathrm{~mm}$ in length.

\section{Juveniles}

After hatching, young Nile tilapia remains with mother and will reenter her mouth for protection if threatened or under unfavorable weather conditions [15].

\section{Habitat Characteristics Temperature}

Nile tilapia are Eurythermal (can tolerate a wide range of temperatures from $8-42{ }^{\circ} \mathrm{C}$ ). It can tolerate temperatures of $8{ }^{\circ} \mathrm{C}$ at night for several hours and prefers temperatures between $28-30{ }^{\circ} \mathrm{C}$ depending on acclimation temperature [19].

\section{Oxygen}

Nile tilapia can tolerate low dissolved oxygen (DO) $(0.1 \mathrm{ppm})$ but grows well in DO levels of $1-3 \mathrm{ppm}$ [19].

\section{Salinity}

Nile tilapia are moderately euryhaline (can withstand salinity range of 11 to $29 \%$ ). It has reduced salinity tolerance when compared to many other introduced tilapias [19].

pH

The ideal $\mathrm{pH}$ range of freshwater culture of Nile tilapia is 6.5 - 9.0 [19].

Ammonia.

This is highly toxic to fish and is mostly caused by heavy application of manure. The normal level of ammonia in ponds is $1.0 \mathrm{ppm}$ [19].

\section{Ingredients in tilapia grower Fish Meal}

According to Raanan Fish Meal Ltd [20], the composition of Fish Meal for tilapia is as below:

Table-4: Composition of Fish Meal

\begin{tabular}{|c|c|c|}
\hline Protein $33 \%$ & $1.1 \%$ & Vitamin A $4500 \mathrm{iu} / \mathrm{kg}$ \\
\hline Fat $\quad 6.0 \%$ & Lysine $1.6 \%$ & Vitamin D3 1050iu/kg \\
\hline Fibre & Meth. + Cyst. $1.1 \%$ & Vitamin E $120 \mathrm{iu} / \mathrm{kg}$ \\
\hline Ash & Copper 3mg/kg & Vitamin C 90mg/kg \\
\hline
\end{tabular}

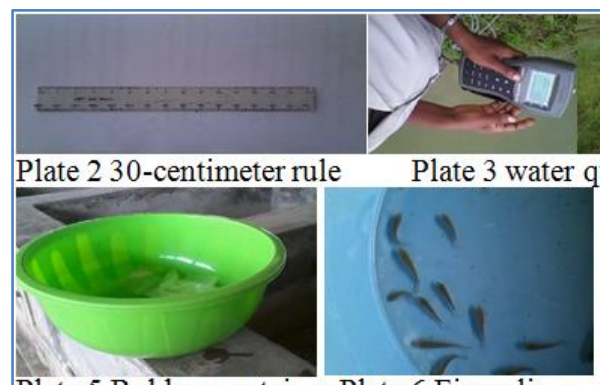

Plate 5 Rubber container Plate 6 Fingerlings

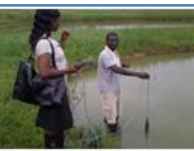

uality sampler

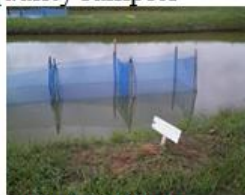

Plate 7 Hapas

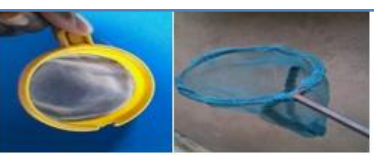

Plate 4 scooping nets

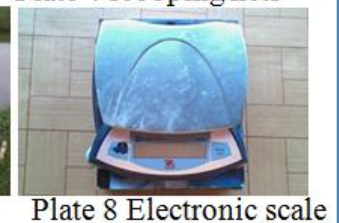

\section{MATERIALS AND METHODS \\ Materials \\ Housing and equipment}

Four ponds were used with three hapas of length $2 \mathrm{~m}$, width $2 \mathrm{~m}$, and height $2 \mathrm{~m}$ dimensions for each. The hapas were erected in the various ponds using poles with nails at both ends with which the length, width and height were hooked on and well stretched in the ponds. Stones of required weight were dropped in the four corners of each hapa to prevent the base from floating up.
Rearing facilities, fish and experimental design

The feeding trial was carried out at the Pilot Aquaculture Centre (PAC) at Tano-Odumasi using all male tilapia fingerlings of average initial weight $1.28 \mathrm{~g}$, total length of $3.98 \mathrm{~cm}$, standard length of $2.14 \mathrm{~cm}$,total width of $1.22 \mathrm{~cm}$ and standard width of $0.96 \mathrm{~cm}$. The fingerlings were kept under continuous observation for one week prior to the start of the experiment and then randomly distributed within twelve (12) hapas in three ponds (each hapa composed of an area of $4 \mathrm{~m}$ square of water capacity) at a stocking density of 20 fingerlings per hapa, with three replicates per dietary treatment in each pond. 


\section{Study area}

The research covered only Kona-Odumasi in Sekyere East District in Ashanti Region of Ghana. The district is about 16 miles away from the Kumasi Metropolis and Mampong Municipality and is located midway between the two towns. According to the district meteorological department, the district is found between latitude of $6^{\circ}$ and $7^{\circ}$ north of the equator. Each replicate received $3 \mathrm{~g}$ of the required treatment for four times a day at a regular interval of two hours for five weeks. The feeding started on the 08/08/11 at 5:00pm and lasted for eight weeks.

\section{Experimental diet and feeding regime (Plates 9 - 12)}

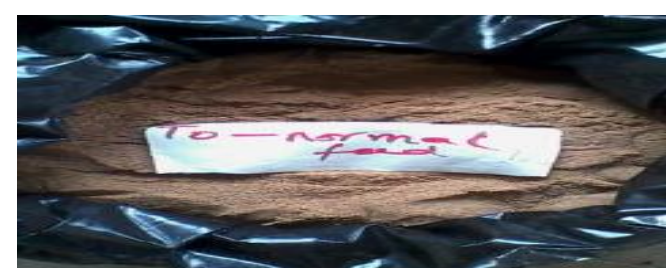

Plate 9 T0-Normal feed used

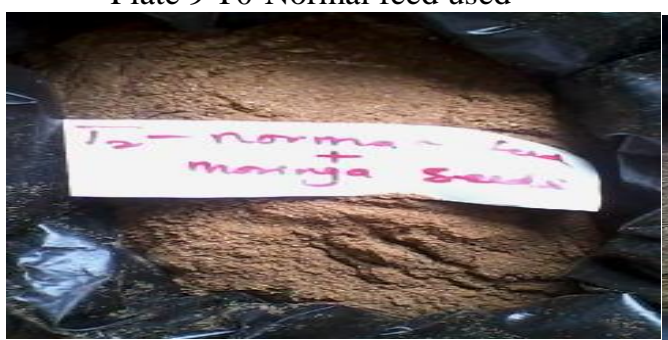

Plate 11 T2-Normal feed + Moringa Seeds

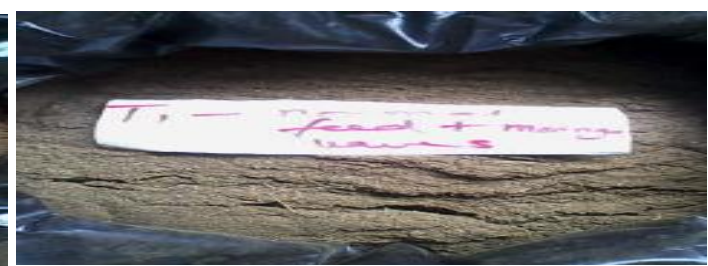

Plate 10 T1-Normalfeed+Moringa Leaves

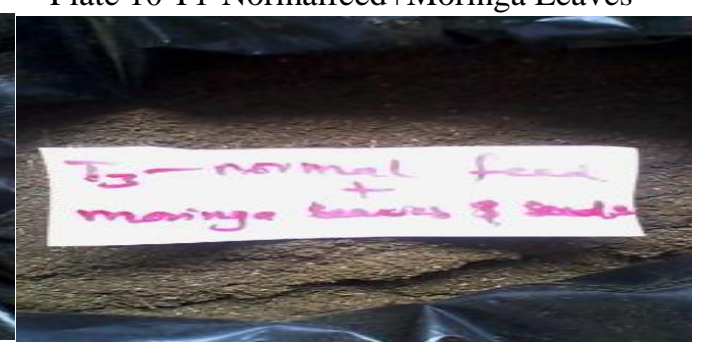

Parameters measured

Water quality of the ponds

Water quality monitoring was done using a ProDSS probe for temperature, $\mathrm{pH}$, Dissolved oxygen, Total dissolved solids, Atmospheric pressure and Ammonia at fortnightly intervals.

\section{Average weight}

The average weight of the fishes was taking by randomly picking any three fingerlings from each replicate of a treatment using a scooping net and weighing them on an electronic scale as shown in plate 13 .

fingerlings were stocked and continued for eight weeks at a regular fortnightly interval.

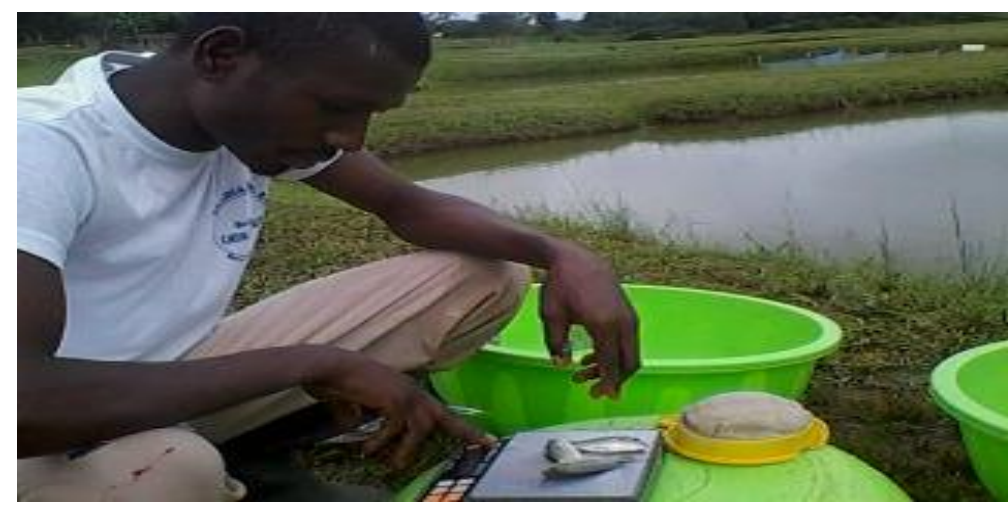

Plate-13: Measurement of the average weight of fishes from fish ponds by Mpanga Isaac Kwadwo at Kona-Adumasi

\section{Total length}

The total lengths of fishes were obtained by using a 30-centimeter rule to measure the length of the randomly scooped fingerlings from the tip of their snout to the tip of the caudal fin. 


\section{Standard length}

With the same fingerlings used for the weight and total length, a 30-centimeter rule was used to measure the length of the fingerlings between the tip of operculum and peduncle to get the standard length.

\section{Total width}

With the same fingerlings used for the weight and total length, a 30-centimeter rule was used to measure the width of the fingerlings by spreading the spiny dorsal fins and taking the width from the tip of the spiny dorsal fins to the base of the pelvic fins.

\section{Standard width}

With the same fingerlings used for the weight and total length, a centimeter rule was used to measure the width of the fingerlings from the base of the spiny dorsal fins to the base of the pelvic fins.

\section{RESULTS AND DISCUSSION Water Quality of the fish ponds}

The results demonstrate water quality of the fish ponds just before, on course, and at the end of the project at a regular interval of two weeks as below using the water quality sampler (Tables $5-8$ ).

Table-5: Water quality in the ponds before stocking them with fingerlings

\begin{tabular}{|c|c|c|c|c|}
\hline Measurement/Parameter & Pond 1 & Pond 2 & Pond 3 & Pond 4 \\
\hline Time & $9: 19 \mathrm{am}$ & $9: 26 \mathrm{am}$ & $9: 30 \mathrm{am}$ & $9: 33 \mathrm{am}$ \\
\hline Temperature $\left({ }^{\circ} \dot{\mathrm{C}}\right)$ & 25.6 & 25.77 & 25.76 & 26.06 \\
\hline$p \mathrm{H}$ & 7.30 & 7.39 & 7.29 & 6.70 \\
\hline Dissolved Oxygen $(\mathrm{mg} / \mathrm{l})$ & 3.15 & 5.21 & 5.82 & 7.14 \\
\hline \% Dissolved Oxygen & 40.1 & 66.5 & 74.3 & 91.6 \\
\hline Total Dissolved Solid $(\mathrm{mg} / \mathrm{l})$ & 33 & 25.7 & 29 & 29 \\
\hline Atmospheric Pressure $(\mathrm{mmHg})$ & 731.7 & 731.6 & 731.7 & 731.7 \\
Ammonia (ppm) & 1.20 & 1.23 & 1.34 & 1.47 \\
\hline
\end{tabular}

Table-6: Water qualities in ponds at the middle of the project. Date: 24/08/2011

\begin{tabular}{|c|c|c|c|c|}
\hline Measurement/Parameter & Pond 1 & Pond 2 & Pond 3 & Pond 4 \\
\hline Time & $8: 30 \mathrm{am}$ & $8: 35 \mathrm{am}$ & $8: 40 \mathrm{am}$ & $8: 45 \mathrm{am}$ \\
\hline Temperature $(\dot{\mathrm{C}})$ & 24.93 & 24.72 & 24.94 & 25.29 \\
\hline$p \mathrm{H}$ & 7.02 & 7.03 & 7.15 & 6.65 \\
\hline Dissolved Oxygen $(\mathrm{mg} / \mathrm{l})$ & 2.20 & 2.41 & 3.25 & 4.51 \\
\hline \%Dissolved Oxygen & 27.7 & 30.3 & 40.9 & 57.2 \\
\hline Total Dissolved solid (mg/l) & 29 & 25 & 31 & 30 \\
\hline Atmospheric Pressure(mmHg) & 731.4 & 731.4 & 731.5 & 731.4 \\
Ammonia (ppm) & 1.30 & 1.28 & 1.24 & 1.50 \\
\hline
\end{tabular}

Table-7: Water quality in the ponds in the middle of the project

\begin{tabular}{|c|c|c|c|c|}
\hline Measurement/Parameter & Pond 1 & Pond 2 & Pond 3 & Pond 4 \\
\hline Time & $7: 19 \mathrm{am}$ & $7: 26 \mathrm{am}$ & $7: 30 \mathrm{am}$ & $7: 33 \mathrm{am}$ \\
\hline Temperature $\left({ }^{0} \dot{\mathrm{C}}\right)$ & 24.9 & 24.77 & 24.76 & 25.06 \\
\hline$p \mathrm{H}$ & 7.31 & 7.36 & 7.24 & 6.70 \\
\hline Dissolved Oxygen $(\mathrm{mg} / \mathrm{l})$ & 2.25 & 2.46 & 3.35 & 4.51 \\
\hline \%Dissolved Oxygen & 40.1 & 66.5 & 74.3 & 91.6 \\
\hline Total Dissolved solid $(\mathrm{mg} / \mathrm{l})$ & 33 & 25.7 & 29 & 29 \\
\hline Atmospheric Pressure $(\mathrm{mmHg})$ & 731.5 & 731.4 & 731.5 & 731.5 \\
\hline Ammonia(ppm) & 1.03 & 1.12 & 1.18 & 1.21 \\
\hline
\end{tabular}

Table-8: Water quality in the ponds at the end of the project

\begin{tabular}{|c|c|c|c|c|}
\hline Measurement Parameter & Pond 1 & Pond 2 & Pond 3 & Pond 4 \\
\hline Time & $8: 20 \mathrm{am}$ & $8: 25 \mathrm{am}$ & $8: 30 \mathrm{am}$ & $8: 40 \mathrm{am}$ \\
\hline Temperature (C) & 25.91 & 25.88 & 25.79 & 26.16 \\
\hline$p \mathrm{H}$ & 7.02 & 7.03 & 7.15 & 6.65 \\
\hline Dissolved Oxygen (mg/l) & 3.25 & 5.21 & 5.92 & 7.12 \\
\hline \%Dissolved Oxygen & 40.1 & 66.5 & 74.3 & 91.6 \\
\hline Total Dissolved solid (mg/l) & 29 & 25 & 31 & 30 \\
\hline Atmospheric Pressure(mmHg) & 731.5 & 731.4 & 731.5 & 731.5 \\
\hline Ammonia (ppm) & 1.10 & 1.11 & 1.15 & 1.20 \\
\hline
\end{tabular}

\section{Average standard length of all-male tilapia}

From table 9, it is clearly shown that the values in the first two weeks for male tilapia fishes that were fed with moringa treatments ranged from $2.24(\mathrm{~T} 0) \mathrm{cm}$ -
$2.56(\mathrm{~T} 2) \mathrm{cm}$ which indicate there was a significant difference between $\mathrm{T} 0$ and $\mathrm{T} 2$ at 0.05 probability level. Growth lengths of T0 and T3 also posed a significant difference at 0.05 probability level. The body lengths 
growth in week 4 also yielded incremental levels between the various treatments applied, ranging from 2.34 (T0) $\mathrm{cm}$ to 3.21 (T2) $\mathrm{cm}$ with a significant difference at 0.05 probability level between all the other treatments and the control. However, week six and eight showed no significant difference at 0.05 probability levels between the entire treatments in terms of standard body lengths. Average performance in terms of average standard Length of the all-male tilapia within each treatment for the eight weeks was: T0-1.50cm, T1$1.68^{\mathrm{b}} \mathrm{cm}, \mathrm{T} 2-1.41 \mathrm{~cm}$, and $\mathrm{T} 3-1.89 \mathrm{~cm}$. From this point of comparison, it could be refereed that growth lengths observed from treatment- T3 (Normal feed + moringa leaves and seeds) performed better than all the other treatments for the eight weeks.

Table-9: Effects of moringa on average standard length (ASL) of all male tilapia in centimeters

\begin{tabular}{|c|c|c|c|c|}
\hline Treatment/growth effect & Week 2 & Week 4 & Week 6 & Week 8 \\
\hline Normal feed used(T0) & $2.24^{\mathrm{c}}$ & $2.34^{\mathrm{c}}$ & $2.91^{\mathrm{a}}$ & $3.74^{\mathrm{a}}$ \\
\hline Normal feed used + moringa leaves (T1) & $2.47^{\mathrm{ab}}$ & $2.94^{\mathrm{ab}}$ & $3.52^{\mathrm{a}}$ & $4.15^{\mathrm{a}}$ \\
\hline Normal feed + moringa seeds (T2) & $2.56^{\mathrm{a}}$ & $3.21^{\mathrm{a}}$ & $3.77^{\mathrm{a}}$ & $3.97^{\mathrm{a}}$ \\
\hline Normal feed + moringa leaves and seeds (T3) & $2.29^{\mathrm{bc}}$ & $2.74^{\mathrm{ab}}$ & $3.57^{\mathrm{a}}$ & $4.18^{\mathrm{a}}$ \\
\hline LSD & 0.21 & 0.72 & 0.61 & 0.83 \\
\hline CV & 4.40 & 12.8 & 8.90 & 10.30 \\
\hline
\end{tabular}

Treatment means with common letters are not significantly different at 0.05 probability level.

\section{Average total length of all male tilapia}

Table-10: Effects of moringa on average total length (ATL) of all male tilapia in centimeters.

\begin{tabular}{|c|c|c|c|c|}
\hline Treatment/growth effect & Week 2 & Week 4 & Week 6 & Week 8 \\
\hline Normal feed used(T0) & $4.32^{\mathrm{a}}$ & $5.08^{\mathrm{b}}$ & $5.83^{\mathrm{b}}$ & $7.36^{\mathrm{a}}$ \\
\hline Normal feed used + moringa leaves (T1) & $4.78^{\mathrm{a}}$ & $5.57^{\mathrm{ab}}$ & $6.80^{\mathrm{ab}}$ & $8.02^{\mathrm{a}}$ \\
\hline Normal feed + moringa seeds (T2) & $4.81^{\mathrm{a}}$ & $6.13^{\mathrm{a}}$ & $7.05^{\mathrm{a}}$ & $8.41^{\mathrm{a}}$ \\
\hline Normal feed + moringa leaves and seeds (T3) & $4.51^{\mathrm{a}}$ & $5.48^{\mathrm{ab}}$ & $6.98^{\mathrm{a}}$ & $7.59^{\mathrm{a}}$ \\
\hline LSD & 0.24 & 0.90 & 1.08 & 1.32 \\
\hline CV & 2.60 & 8.10 & 8.10 & 8.4 \\
\hline
\end{tabular}

Treatment means with common letters are not significantly different at 0.05 probability level.

According to Cimbaro, [21] a typical tilapia will obtain a total length of $25 \mathrm{~cm}$ by the second year. From table 4.2 above, the first two weeks gave a rage of value from 4.32 (T0) $\mathrm{cm}-4.81$ (T2) cm indicating a significant difference at 0.05 probability levels between $\mathrm{T} 0$ and $\mathrm{T} 1, \mathrm{~T} 0$ and $\mathrm{T} 2, \mathrm{~T} 1$ and $\mathrm{T} 3$, and $\mathrm{T} 2$ and $\mathrm{T} 3$ respectively as shown in table 4.2 above. The total body length growth pattern observed in Week four similarly varied from $5.08(\mathrm{~T} 0) \mathrm{cm}-6.13(\mathrm{~T} 2) \mathrm{cm}$. However, the mean total body lengths showed significant difference at 0.05 probability levels between $\mathrm{T} 0$ and $\mathrm{T} 2$ only. The range of values for total body lengths in week six varied from $5.83(\mathrm{~T} 0) \mathrm{cm}-7.05(\mathrm{~T} 2) \mathrm{cm}$ and further revealed a significant difference at 0.05 level between them. No significant difference in body length was recorded in week eight. Critical analyses of the view expressed by Cimbora as stated above compared with the growth length responses of $7.05 \mathrm{~cm}$ obtained from the moringa treatments T2 (i.e. Normal feed + moringa seeds) by the eighth week, it could be ascertained that such a treatment combination is a promising option to embrace for expected higher total body lengths. For performance within treatment for total length of all al male tilapia within the eight weeks, we generally had - T0 - 5.04 $\mathrm{cm}, \mathrm{T} 1-3.24 \mathrm{~cm}, \mathrm{~T} 2-3.60 \mathrm{~cm}$ and T3 $-3.08 \mathrm{~cm}$. From within the treatment performance for the eight weeks, T1 seems to have recorded the highest value of $8.41 \mathrm{~cm}$. Various recent studies on the integration of Moringa
Leaf Meal in fish feeds revealed that it impacted positively on Nile Tilapia body lengths and other growth parameters and was proven to have effectively alleviated starvation stress through retaining the enhanced growth and stress indices [22]. It was generally confirmed that, Moringa oleifera seed and leaf supplementation to Nile tilapia feeds and culture has a positive effect as a growth promoter, natural antistress phyto-therapy with enormous prophylactic, pharmacognostic, pharmacological and nutritional values [23-25].

\section{Average standard width of the all-male tilapia}

From table 11, the values obtained from performance within the treatments were: T0 $-0.9 \mathrm{~cm}$, T1 $-0.98 \mathrm{~cm}, \mathrm{~T} 2-0.96 \mathrm{~cm}$, and T3 $-0.91 \mathrm{~cm}$ with T2 recording slightly high performance within the treatments in terms of standard width. From table 4.3 above, it could be clearly seen that at 0.05 probability levels there was no significant difference between the treatments in week two and eight with regards to standard width. However, there was a significant difference at 0.05 probability levels for week four between $\mathrm{T} 0$ and $\mathrm{T} 2$ with the range of values been 1.62 (T0) $\mathrm{cm}-1.94(\mathrm{~T} 2) \mathrm{cm}$. For week six, the values ranged from 1.99 (T0) - 2.41 (T2) indicating a significant difference between $\mathrm{T} 0$ and $\mathrm{T} 2$, and $\mathrm{T} 0$ and $\mathrm{T} 3$ at 0.05 probability levels. 
Table-11: Effects of moringa on average standard width (ASW) of all male tilapia in centimeters

\begin{tabular}{|l|l|l|l|l|}
\hline Treatment/growth effect & Week 2 & Week 4 & Week 6 & Week 8 \\
\hline Normal feed used(T0) & $1.34^{\mathrm{a}}$ & $1.62^{\mathrm{b}}$ & $1.99^{\mathrm{b}}$ & $2.24^{\mathrm{a}}$ \\
\hline Normal feed used + moringa leaves (T1) & $1.43^{\mathrm{a}}$ & $1.69^{\mathrm{ab}}$ & $2.10^{\mathrm{ab}}$ & $2.41^{\mathrm{a}}$ \\
\hline Normal feed + moringa seeds (T2) & $1.48^{\mathrm{a}}$ & $1.94^{\mathrm{a}}$ & $2.41^{\mathrm{a}}$ & $2.44^{\mathrm{a}}$ \\
\hline Normal feed + moringa leaves and seeds (T3) & $1.41^{\mathrm{a}}$ & $1.89^{\mathrm{ab}}$ & $2.37^{\mathrm{a}}$ & $2.32^{\mathrm{a}}$ \\
\hline LSD & 0.21 & 0.30 & 0.33 & 0.26 \\
\hline CV & 7.40 & 8.50 & 7.50 & 5.40 \\
\hline
\end{tabular}

Treatment means with common letters are not significantly different at 0.05 probability level.

\section{Average total width of the al male tilapia}

From table 12 the data shows that within the treatments, the performance for average total widths of the tilapia fishes were; T0-1.33cm, T1-1.61 cm, T2-1.32 $\mathrm{cm}, \mathrm{T} 3-1.41 \mathrm{~cm}$ with $\mathrm{T} 1$ having a higher value than the rest of the treatments. In terms of performance, it is clear that the figures obtained were very close and probably suggest that there was no significance between the treatments. From table 11 above, it is further shown that there was no significant difference the fishes at 0.05 probability level for weeks 2,4 , and 6 in terms of average total width of the all male tilapia but for week 8 , a significant difference at 0.05 probability level was recorded between $\mathrm{T} 0$ and $\mathrm{T} 1$ with a range of values varying between $2.91(\mathrm{~T} 0) \mathrm{cm}-3.31(\mathrm{~T} 1) \mathrm{cm}$.

Table-12: Effects of moringa on average total width (ATW) of the all male tilapia in centimeters

\begin{tabular}{|l|l|l|l|l|}
\hline Treatment/growth effect & Week 2 & Week 4 & Week 6 & Week 8 $^{\text {Wed }}$ \\
\hline Normal feed used(T0) & $1.58^{\mathrm{a}}$ & $1.92^{\mathrm{a}}$ & $2.33^{\mathrm{a}}$ & $2.91^{\mathrm{b}}$ \\
\hline Normal feed used + moringa leaves (T1) & $1.70^{\mathrm{a}}$ & $2.04^{\mathrm{a}}$ & $2.43^{\mathrm{a}}$ & $3.31^{\mathrm{a}}$ \\
\hline Normal feed + moringa seeds (T2) & $1.69^{\mathrm{a}}$ & $2.31^{\mathrm{a}}$ & $2.51^{\mathrm{a}}$ & $3.01^{\mathrm{ab}}$ \\
\hline Normal feed + moringa leaves and seeds (T3) & $1.62^{\mathrm{a}}$ & $2.22^{\mathrm{a}}$ & $2.67^{\mathrm{a}}$ & $3.03^{\mathrm{ab}}$ \\
\hline LSD & 0.17 & 0.40 & 0.52 & 0.35 \\
\hline CV & 5.10 & 9.30 & 10.40 & 5.70 \\
\hline
\end{tabular}

Treatment means with common letters are not significantly different at 0.05 probability level

Table-13: Effects of moringa on average weight (AW) of the all-male tilapia in grams

\begin{tabular}{|c|c|c|c|c|}
\hline Treatment/growth effect & Week 2 & Week 4 & Week 6 & Week 8 \\
\hline Normal feed used(T0) & $1.54^{\mathrm{b}}$ & $2.56^{\mathrm{b}}$ & $4.33^{\mathrm{b}}$ & $7.61^{\mathrm{b}}$ \\
\hline Normal feed used + moringa leaves (T1) & $2.02^{\mathrm{ab}}$ & $3.33^{\mathrm{b}}$ & $5.82^{\mathrm{ab}}$ & $9.33^{\mathrm{ab}}$ \\
\hline Normal feed + moringa seeds (T2) & $2.30^{\mathrm{a}}$ & $4.89^{\mathrm{a}}$ & $6.94^{\mathrm{a}}$ & $10.82^{\mathrm{a}}$ \\
\hline Normal feed + moringa leaves and seeds (T3) & $1.72^{\mathrm{b}}$ & $3.83^{\mathrm{ab}}$ & $5.78^{\mathrm{ab}}$ & $9.50^{\mathrm{ab}}$ \\
\hline LSD & 0.51 & 1.29 & 1.50 & 3.00 \\
\hline CV & 13.50 & 17.60 & 13.10 & 16.10 \\
\hline
\end{tabular}

Treatment means with common letters are not significantly different at 0.05 probability level.

Recent studies discovered that, fish fed with Moringa oleifera leaf diet containing $100 \mathrm{~g} / \mathrm{kg}$ demonstrated better growth than at the other inclusion levels, but it was not significantly different from the control groups [26]. The digestibility coefficient and protein digestibility were lower in fish fed with a higher inclusion of moringa leaf in the diets at $p<0.05$. Pepsin digestibility and serum biochemical parameters were also not comparatively different among all treatments at $p>0.05$ with existing literature [27]. These studies further indicated that dietary moringa leaf could be included in most fish including the Bocourti's catfish diet at possibly not over $100 \mathrm{~g} / \mathrm{kg}$ fish without a negative effect on the growth, feed utilization, digestibility and serum biochemistry [26, 28].

\section{Average weight of the all-male tilapia}

According to Makkar et al., [13], the \% dry matter of crude protein and gross energy is higher in moringa seeds than in leaves as in table 13. Now from table 12 above, the range of values from the effects of moringa on average weight (AW) of the all male tilapia in feed trials for week varied from1.54(T0) $\mathrm{g}-2.30$ (T2) $\mathrm{g}$ which shows a significant difference at 0.05 probability levels between $\mathrm{T} 0$ and $\mathrm{T} 2$, and $\mathrm{T} 2$ and $\mathrm{T} 3$ in terms of average weight. In week four (4) however, the weight of the all-male Tilapia increased and ranged from 2.56 (T0) $g-4.89$ (T2) g based on the effect of the moringa feed supplement trials. There was further a significant difference in weight at 0.05 probability levels between $\mathrm{T} 0$ and $\mathrm{T} 2$, and $\mathrm{T} 1$ and $\mathrm{T} 2$. The trend in weight gain following the moringa feed supplement trials in Week eight (8) followed a similar trend as in week six. Within treatment performance of the average weight of the all male tilapia for all the treatments, the values obtained were: T0-6.07 g, T1-7.31 g, T2-8.52 g, T3- $7.78 \mathrm{~g}$. the highest value (8.52) g of mean body weight recorded from $\mathrm{T} 2$ could be related to \% dry matter of the crude protein levels in moringa seeds and leaves as previously ascertained by Makkar et al., [13]. 


\section{CONLUSION}

The study demonstrated, significant differences between $\mathrm{T} 0$ and $\mathrm{T} 2$, an indication that $\mathrm{T} 2$ performed better as compared to the other moringa treatments at 0.05 probabilities. Hence, the null hypothesis that there was no significant difference between the different moringa treatments was refuted. Growth rate of the fingerlings at the early stage of the work was rather rapid as compared to the later part within eight weeks duration of the experiment. This may be attributable to the fact that the number of times for feeding was reduced from four times to thrice with incremental quantity of the feed administered at a given time. It was observed that the all-male tilapia was effectively feeding on the surfaces of the pond where aeration is high; hence some feed might be wasted when it sunk to the bottom of hapas. With regards to the effect on water quality, both the seeds and leaves of moringa did not impact significant effect on the water parameters as the values recorded in the four weeks fell within the expected ranges.

\section{RECOMMENDATION}

It is recommended that both seeds and leaves of moringa should be palette with normal feed to ensure that the feed float without sinking during the design and administration of feeding trials for scientific studies on growth effects and to further prevent the fish from doing selective feeding. Therefore, the experiment may be repeated with the above recommendations.

\section{ACKNOWLEDGEMENT}

The author's express sincere gratitude to $\mathrm{Mr}$. Francis Adjei, Garbi and Sani of Tano-Dumasi Pilot Aquaculture Center for supporting the research with suggestions and encouragement.

\section{REFERENCES}

1. Naylor, R.L., R.J. Goldberg, J.H. Primavera, N. Kautsky, M.C. Beveridge, J. Clay, C. Folke, J. Lubchenco, Mooney, H., \& M. Troell. (2000). Effect of aquaculture on world fish supplies. Nature, 405:1017-1024.

2. FAO. (2000). Yearbook of Fishery Statistics 1998. Vol. 86/2. Aquaculture production. FAO Statistics Series No. 154 and Fisheries Series No. 56, Rome, FAO. 182.

3. Tacon, A. G. J., Forster, I. P. (2001). Global trends and challenges to aquaculture and aquafeed development in the new millennium. Accessed from. http://www.seaweb.org/AAAS/trends html on 3-7-2001.

4. International Fishmeal and Fish Oil Manufacturers Association (IFOMA). (2000). Predicted use of fishmeal and fish oil in aquaculture - revised estimate. IFOMA Update No. 98, April 2000, Potters Bar, UK.

5. Nyavor, C. B., \& Sedddoh, S. (1991). Ghana Association of Science Teachers (Biology).
Macmillan Educational Ltd. Unimax Publishers, London, UK; 298-299.

6. Engar, D. E., Kormelink, J.R., Rose and Smith, J. R. (1991). Concept in Biology. Wm. C. Brown Publishers, USA.P. 250.

7. Food and Agriculture Organization (FAO) Food Nutrition and Agriculture International Conference on Nutrition. Rome, Italy, 230-232.

8. Kassam, L. (2014). Aquaculture and food security, poverty alleviation and nutrition in Ghana: Case study prepared for the Aquaculture for Food Security, Poverty Alleviation and Nutrition project. World Fish, Penang, Malaysia. Project Report: 2014-48.

http://pubs.iclarm.net/resource_centre/2014-48.pdf.

9. FAO. (2016). Fishery and Aquaculture Country Profile, the Republic of Ghana. Food and Agriculture Organization of the United Nations, Fisheries Division. Part I overview and main indicators. http://www.fao.org/fishery/facp/GHA/en.

10. Hardy, R.W. (2000). New developments in aquatic feed ingredients, and potential of enzyme supplements. In: Cruz-Suarez, L. E., Ricque-Marie, D., Tapia Salazar, M., Olvera-Novoa, M. A., Civera-Cerecedo, R., (Eds.), Advances en Nutricion Acuicola V. Memorias del V Simposium Internacional de Nutricion Acuicola. 19-22 November, 2000, Merida, Yucatan, Mexico.

11. World Health Organization (WHO). (2000). FiftyThird World Health Assembly (Report on Infant and Young Child Nutrition). www.who.mt/gb/ebwa/pdffiles.03/2000.02/2005.

12. Foidl, N., Makkar, H. P. S., \& Becker, K. (2001). The potential of Moringa oleifera for agricultural and industrial uses. The miracle tree: The multiple attributes of Moringa, 45-76.

13. Makkar, H.P.S., Becker, K., (1997). Nutrients and antiquality factors in different morphological parts of the Moringa oleifera tree. J. Agr. Sci. Cambridge 128, 311-322.

14. Florida Fish \& Wildlife Conservation Commission (FWC). (2001-2020). The internal and external Anatomy of Florida Fish. https://www.visitflorida.com/en-us/things-todo/florida-fishing/internal-and-external-anatomyof-a-fish.html.

15. Farming, P. (2020). Aquaculture: Tilapia Fish Farming Information and A Complete A to Z Guide. https://farmingpedia.com/tilapia-fishfarming-information-and-a-complete-a-to-z-guide/

16. Tejas, G. H., Umang, J. H., Payal, B. N., Tusharbinu, D. R., \& Pravin, T. R. (2012). A panoramic view on pharmacognostic, pharmacological, nutritional, therapeutic and prophylactic values of Moringa olifera Lam. Int. Res. J. Pharm, 3, 1-7.

17. Turner, G.F., \& R.L. Robinson. (2000). Reproductive biology, mating systems and parental care, p. 33-58 in M.C.M. Beveridge and B.J. 
McAndrew (eds.) Tilapias: Biology and Exploitation. Kluwer Academic Press, Great Britain.

18. Duponchelle, F., P. Cecchi, D. Corbin, J. Nunez., \& M. Legendre (2000). Variations in fecundity and egg size of female Nile tilapia, Oreochromis niloticus, from man-made lakes of Cote D'Ivoire. Environmental Biology of Fishes 57:155-170.

19. Garrigues, Ph., Barth, H., Walker, C.H., \& Narbonne, J. F. (2001). Biomarkers in Marine Organisms. A Practical Approach. 1st Edition, Elsevier Science- Hardcover ISBN: 9780444829139, eBook ISBN: 9780080528045, $7^{\text {th }}$ November 2001: 572.

20. Raanan Fish Meal Ltd. (2010). Composition of Fish Meal I.Z MIout MP. Oshrat, Isreal. www.ranaanfishfeed.com.28/06/11.

21. Cimbaro, J. (2000). Internal Anatomy of fish. fwc. www.florida.fisheries.com.22/06/2011.

22. Standern, B.T., Peggs, D.L., Rawlings, M.D., Foey, A. Davies, S. J., Santos, G. A. and Merrifie, D. L. (2016). Dietry administration of a commercial mixed-species probiotic improves growth performance and modulates the intestinal immunity of Oreochromis niloticus. Fish and Shellfish Immunology, 49, 417-435.

23. Elabd, H., Soror, E., El-Asely, A., El-Gawad, E. A., Abbass, A. (2019). Dietry supplementation of Moringa leaf for Nile tilapia Oreochromis niloticus: Effect on growth and stress indices. The Egyptian Journal of Aquatic Research, 45(3): 265271. https://doi.org/10.1016/j.ejar.2019.05.009
24. Nacimento, J.A., Magnani, M., Sousa, J.M.B., Araújo, K.L.G.V, Epaminondas, P.S., Souza, A.S., Souza, A. L., Silva, M.C.D. and Souza, A. G. (2016). Assessment of the antioxidant effects of Moringa oleifera Lam. Extracts in fish oil during storage. J. Food Process. Preser., 40, pp.29-36.

25. Tejas, G.H., Umang, J. H., Payal, B. N., Tusharbinu, D. R., \& Pravin T. R. (2012). A panoramic view on pharmacognostic, pharmacological, nutritional, therapeutic and prophylactic values of Moringa oleifera Lam. Int. Res. J. Pharm., 3, 1-7.

26. Puycha, K., Yuangsoi, B., Charoenwattanasak, S., Wongmaneeprateep, S. Niamphithak, P. and Wiriyapattanasub, P. (2017). Effect of moringa (Moringa oleifera) leaf supplementation on growth performance and feed utilization of Bocourti's catfish (Pangasius bocourti). Agriculture and Natural Resources, 51(4): 286-291

27. Richter, N., Siddhuraju, P., Becker, K. (2003). Evaluation of nutritional quality of moringa (Moringa oleifera Lam.) leaves as an alternative protein source for Nile tilapia (Oreochromis niloticus L.). Aquaculture, 217(1-4), 599-611.

28. Afuang, W., Siddhuraju, P., \& Becker, K. (2003). Comparative nutritional evaluation of raw, methanol extracted residues and methanol extracts of moringa (Moringa oleiera lam.) leaf on growth performance and feed utilization in Nile tilapia (Oreochromis niloticus L.). Aquac. Res., 34, $1147-$ 1159 .

\section{APPENDICES}

\section{Appendix Table 1 Statistical Data}

VARIATES FOR ALL THE TREATMENTS USED:

A. Variate for average standard length of all male tilapia for the two (2) weeks

Source of variation d.f. s.s. m.s. v.r. F pr.

$\begin{array}{lllll}\text { Replicates stratum } 2 & 0.14972 & 0.07486 & 6.86\end{array}$

Replicates. *Units* stratum

\begin{tabular}{|c|c|c|c|}
\hline Treatment & 3 & 0.19549 & 0.06516 \\
\hline Residual & 6 & 0.06548 & 0.01091 \\
\hline Total & 11 & 0.41069 & \\
\hline
\end{tabular}

B. Variate for average standard length of all male tilapia for the four (4) weeks

Source of variation d.f. $\quad$ s.s. m.s. v.r. F pr.

$\begin{array}{lllll}\text { Replicates stratum } & 2 & 0.0568 & 0.0284 & 0.22\end{array}$

Replicates. *Units* stratum

$\begin{array}{lcccc}\text { Treatment } & 3 & 1.2080 & 0.4027 & 3.120 .109 \\ \text { Residual } & 6 & 0.7740 & 0.1290 & \\ \text { Total } & 11 & 2.0389 & & \end{array}$

C. Variate for average standard length of all male tilapia for the six (6) weeks

Source of variation d.f. $\quad$ s.s. m.s. $\quad$ v.r. F pr.

$\begin{array}{lllll}\text { Replicates stratum } & 2 & 0.25912 & 0.12956 & 1.38\end{array}$

Replicates. *Units* stratum

\begin{tabular}{|c|c|c|c|}
\hline Treatment & 3 & 1.23177 & 0.41059 \\
\hline Residual & 6 & 0.56168 & 0.09361 \\
\hline Total & 11 & 2.05257 & \\
\hline
\end{tabular}


D. Variate for average standard length of all male tilapia for the eight (8) weeks

Source of variation d.f. $\quad$ s.s. m.s. v.r. F pr.

$\begin{array}{lllll}\text { Replicates stratum } & 2 & 0.0225 & 0.0112 & 0.07\end{array}$

Replicates. *Units* stratum

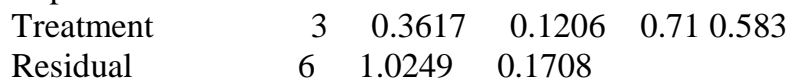

Total $\quad 11 \quad 1.4091$

E. Variate for average total length of all male tilapia for two (2) weeks

Source of variation d.f. $\quad$ s.s. m.s. v.r. F pr.

$\begin{array}{lllll}\text { Replicates stratum } \quad 2 & 0.40402 & 0.20201 & 13.88\end{array}$

Replicates. *Units* stratum

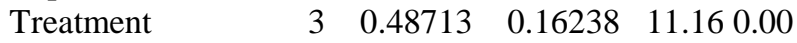

$\begin{array}{llll}\text { Residual } & 6 & 0.08732 & 0.01455\end{array}$

Total $\quad 11 \quad 0.97847$

F. Variate for average total length of all male tilapia for four (4) weeks

Source of variation d.f. $\quad$ s.s. m.s. v.r. F pr.

$\begin{array}{lllll}\text { Replicates stratum } \quad 2 & 1.1928 & 0.5964 & 2.95\end{array}$

Replicates. *Units* stratum

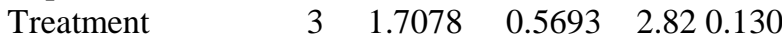

$\begin{array}{llll}\text { Residual } & 6 & 1.2125 & 0.2021\end{array}$

Total $\quad 11 \quad 4.1131$

G. Variate for average total length of al male tilapia for six (6) weeks

Source of variation d.f. $\quad$ s.s. m.s. v.r. F pr.

$\begin{array}{lllll}\text { Replicates stratum } & 2 & 0.4243 & 0.2121 & 0.73\end{array}$

Replicates. *Units* stratum

$\begin{array}{llllll}\text { Treatment } & 3 & 2.8581 & 0.9527 & 3.27 & 0.101\end{array}$

$\begin{array}{llll}\text { Residual } & 6 & 1.7483 & 0.2914\end{array}$

Total $\quad 11 \quad 5.0307$

H. Variate for average total length of all male tilapia for eight (8) weeks

Source of variation d.f. $\quad$ s.s. m.s. v.r. F pr.

$\begin{array}{lllll}\text { Replicates stratum } & 2 & 0.0783 & 0.0392 & 0.09\end{array}$

Replicates. *Units* stratum

Residual $\quad 6 \quad 2.6199 \quad 0.4366$

Total $\quad 11 \quad 4.6731$

I. Variate for average standard width of all male tilapia for two (2) weeks

Source of variation d.f. $\quad$ s.s. m.s. v.r. F pr.

$\begin{array}{lllll}\text { Replicates stratum } & 2 & 0.07280 & 0.03640 & 3.27\end{array}$

Replicates. *Units* stratum

$\begin{array}{llllll}\text { Treatment } & 3 & 0.02903 & 0.00968 & 0.87 & 0.507\end{array}$

$\begin{array}{llll}\text { Residual } \quad 6 & 0.06680 & 0.01113\end{array}$

Total $\quad 11 \quad 0.16863$

J. Variate for average standard width of all male tilapia for four (4) weeks

Source of variation d.f. s.s. m.s. v.r. F pr.

$\begin{array}{lllll}\text { Replicates stratum } & 2 & 0.03860 & 0.01930 & 0.84\end{array}$

Replicates. *Units* stratum

$\begin{array}{llllll}\text { Treatment } & 3 & 0.21363 & 0.07121 & 3.09 & 0.111\end{array}$

$\begin{array}{llll}\text { Residual } & 6 & 0.13827 & 0.02304\end{array}$

$\begin{array}{lll}\text { Total } & 11 & 0.39050\end{array}$

K. Variate for average standard width of all male tilapia for six (6) weeks

Source of variation d.f. $\quad$ s.s. m.s. v.r. F pr.

$\begin{array}{lllll}\text { Replicates stratum } & 2 & 0.08202 & 0.04101 & 1.47\end{array}$

Replicates. *Units* stratum

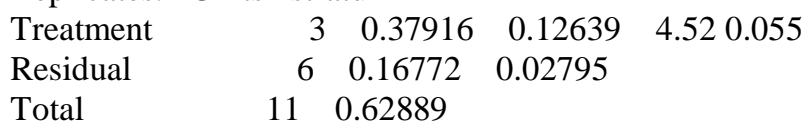


L. Variate for average standard width of all male tilapia for eight (8) weeks

Source of variation d.f. $\quad$ s.s. m.s. v.r. F pr.

$\begin{array}{lllll}\text { Replicates stratum } \quad 2 & 0.09755 & 0.04878 & 2.98\end{array}$

Replicates. *Units* stratum

$\begin{array}{llllll}\text { Treatment } & 3 & 0.07290 & 0.02430 & 1.48 & 0.311\end{array}$

$\begin{array}{llll}\text { Residual } & 6 & 0.09825 & 0.01638\end{array}$

$\begin{array}{lll}\text { Total } & 11 & 0.26870\end{array}$

M. Variate for average total width of all male tilapia for two (2) weeks

Source of variation d.f. $\quad$ s.s. m.s. v.r. F pr.

$\begin{array}{lllll}\text { Replicates stratum } \quad 2 & 0.039267 & 0.019633 & 2.78\end{array}$

Replicates. *Units* stratum

$\begin{array}{llllll}\text { Treatment } & 3 & 0.029467 & 0.009822 & 1.39 & 0.333\end{array}$

Residual $\quad 6 \quad 0.042333 \quad 0.007056$

Total $11 \quad 0.111067$

N. Variate for average total width of all male tilapia for four (4) weeks

Source of variation d.f. $\quad$ s.s. m.s. v.r. F pr

$\begin{array}{lllll}\text { Replicates stratum } & 2 & 0.12667 & 0.06333 & 1.62\end{array}$

Replicates. *Units* stratum

$\begin{array}{llllll}\text { Treatment } & 3 & 0.27176 & 0.09059 & 2.31 & 0.176\end{array}$

$\begin{array}{llll}\text { Residual } & 6 & 0.23487 & 0.03914\end{array}$

$\begin{array}{lll}\text { Total } & 11 & 0.63329\end{array}$

O. Variate for average total width of all male tilapia for six (6) weeks

Source of variation d.f. $\quad$ s.s. m.s. v.r. F pr.

$\begin{array}{lllll}\text { Replicates stratum } & 2 & 0.03607 & 0.01803 & 0.27\end{array}$

Replicates. *Units* stratum

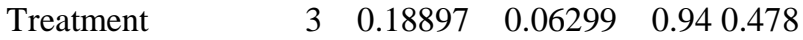

$\begin{array}{llll}\text { Residual } & 6 & 0.40253 & 0.06709\end{array}$

$\begin{array}{lll}\text { Total } & 11 & 0.62757\end{array}$

P. Variate for average total width of all male tilapia for eight (8) weeks

Source of variation d.f. $\quad$ s.s. m.s. v.r. F pr.

$\begin{array}{lllll}\text { Replicates stratum } & 2 & 0.17082 & 0.08541 & 2.83\end{array}$

Replicates. *Units* stratum

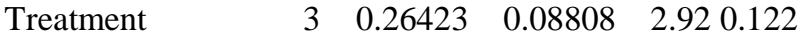

$\begin{array}{llll}\text { Residual } & 6 & 0.18105 & 0.03018\end{array}$

Total $\quad 11 \quad 0.61609$

Q. Variate for average weight of all male tilapia for two (2) weeks

Source of variation d.f. $\quad$ s.s. m.s. v.r. F pr.

$\begin{array}{lllll}\text { Replicates stratum } & 2 & 0.10362 & 0.05181 & 0.80\end{array}$

Replicates. *Units* stratum

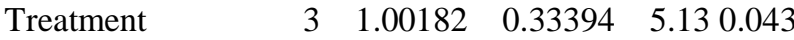

$\begin{array}{llll}\text { Residual } & 6 & 0.39065 & 0.06511\end{array}$

Total $\quad 11 \quad 1.49609$

R. Variate for average weight of all male tilapia for four (4) weeks

Source of variation d.f. $\quad$ s.s. m.s. v.r. F pr

$\begin{array}{lllll}\text { Replicates stratum } & 2 & 1.3443 & 0.6721 & 1.62\end{array}$

Replicates. *Units* stratum

$\begin{array}{llllll}\text { Treatment } & 3 & 8.5722 & 2.8574 & 6.89 & 0.023\end{array}$

$\begin{array}{llll}\text { Residual } & 6 & 2.4865 & 0.4144\end{array}$

Total $11 \quad 12.4030$

S. Variate for average weight of all male tilapia for six (6) weeks

Source of variation d.f. $\quad$ s.s. m.s. v.r. F pr.

$\begin{array}{lllll}\text { Replicates stratum } & 2 & 0.3093 & 0.1546 & 0.27\end{array}$

Replicates. *Units* stratum 


\begin{tabular}{|c|c|c|c|c|}
\hline Treatment & 3 & 10.2978 & 3.4326 & 6.100 .030 \\
\hline Residual & 6 & 3.3741 & 0.5624 & \\
\hline Total & 11 & 13.9812 & & \\
\hline
\end{tabular}

T. Variate for average weight of all male tilapia for eight (8) weeks

\begin{tabular}{|c|c|c|c|c|}
\hline Source of variation & d. & S.s. & m.s. & v.r. F pr. \\
\hline Replicates stratum & 2 & 3.002 & 1.501 & 0.67 \\
\hline Replicates. *Units* & strat & um & & \\
\hline Treatment & 3 & 15.653 & 5.218 & 2.320 .175 \\
\hline Residual & 6 & 13.513 & 2.25 & \\
\hline Total & & 32.169 & & \\
\hline
\end{tabular}

\begin{tabular}{|l|l|}
\hline \multicolumn{2}{|l|}{ Appendix Table 2: Nile Tilapia Fish Breed Profile } \\
\hline Phylogeny scientific background: \\
\hline Name & Nile Tilapia \\
\hline Kingdom & Animalia \\
\hline Phylum & Chordata \\
\hline Class & Actinopterygii \\
\hline Order & Perciformes \\
\hline Family & Cichildae \\
\hline Genus & Oreochromis \\
\hline Species & O. niloticus \\
\hline Binomial Name & Oreochromis niloticus \\
\hline Other Names & Boulti, nilotica, mango fish \\
\hline Breed Purpose & Mainly food and scientific research \\
\hline Special Notes & $\begin{array}{l}\text { A very fast-growing and prolific breeding fish species. Commercially a very important } \\
\text { fish species, cultured in many countries throughout the world with up to } 9 \text { years } \\
\text { lifespan, can tolerate brakish water, survive temperatures between } 8 \text { and } 42{ }^{\circ} \text { C, very } \\
\text { tasty, has a great demand in the market, used mainly for food. }\end{array}$ \\
\hline Breeding Method & Natural and artificial \\
\hline Weight & Usually grow 400-500 grams in commercial farms, but can grow up to $4.3 \mathrm{~kg}$ \\
\hline Water Type & Brakish water \\
\hline Climate Tolerance & Almost all climates \\
\hline Body Color & Body color can vary \\
\hline Rarity & Common \\
\hline Availability & Worldwide \\
\hline
\end{tabular}

Source: https://www.roysfarm.com/nile-tilapia-fish 